Chapter 26

\author{
CASE HISTORY OF SHORE PROTECTION AT PRESQUE ISLE \\ PENINSULA, PA. \\ Charles स. Lee \\ Great Lakes Division, Corps of Ingineers \\ Chicago 15, Illinois
}

\title{
INTRODISCTI ON
}

The beach protection aspects rather than the importance to navigation of Presque Isle Peninsula is stressed in this paper. The history of the locality is so extensive that only that which bears on beach protection and the portion deemed pertinent to provide background to the early importance of the site will be related. The three main reasons for protecting Presque Isle Peninsula are as follows: for protection of the natural harbor at Brie, Pennsylvania; for the preservation of the beaches which provide Pennsylvania's only public lakeshore recreational area on Iake Frie; and to prevent destruction of the only land access to the facilities on the peninsula. It is reported that in 1947 over $1,500,000$ people visi ted the 3,200 acre Presque Isle State Park. There are also located on the peninsula installations of the Mrie Water Works, tie United States Coast Guard and the Pennsylvania State Department of Fisheries.

\section{GHATRA TESCRIPIION}

Presque Isle Peninsula is located at Irie on the south shore of Lake Erie, 78 miles southwest of Buffalo, New York, and 102 miles east-northeast of Cleveland, Ohio. Iake Brie, one of the Great Lakes chain, is an elongated body of fresh water, 9,940 square miles in area, lying between Buffalo and Toledo, Ohio. Its maximum length and widh are 241 and $57 \mathrm{miles}$, respectively, with its major axis lying in an east-northeast direction. The lake is comparatively shalloy wl th a maxtmum depth of 210 feet and an average depth of about 58 feet. The 30 -foot depth curve along the south shore of the lake is approximately one mile offshore. Bxcept at the extreme ends, the lake is free of shoals and islands. Presque Isle Peninsula and Long Point, Canada, a similar peninsula to the north project from opposite shores and constrict the width of the lake at this point to 26 miles (Fig. 1).

Presque Isle Peninsula is a compound recurved sandspit joined to the mainland at the southerly end by a narrow section called "the neck". The peninsula extends in a northeasterly direction for a distance of 6-1/4 miles and broadens from a minimum width of approximately 250 feet at the neck to a maximum width of $1-1 / 4$ miles near the distal end. The northern end of the peninsula terminates in several low, flat, cuspate bars. The north pier of Irie Harbor entrance channel is joined to the distal ond. The south pier of the entrance channel is joined to the mainland by a tombolo at a point 5 miles eastward of the root of the peninsula.

The general elevation of the spit is low, rising to a height of about 5 feet above average lake level. There are four major and several minor 
beach ridges or dunes, extending across the spit in an east-and-west direction, which rise to an average elevation of about 20 feet above lake level. The wide part of the spit incorporates several shallow lagoons and marshes.

The lakeward shore 1s, in general, a regralar flat sandy beach ranging in width from zero at sections where the neck is protected by sea wells to 250 feet at the distal end. Its regularity and continuity are broken onls at points where protective works have altered the natural alignment of the shore 1ine. The bay shore is characterized by narrov beaches, flat offshore slopes, and numerous small bays, coves and 1nlets. Bixcept on the beach areas, the peninsula sustains a thick growth of almost every virilety of trees and shrubs comon to these latitudes.

The peninsula is exposed to storm winds from southwest through north to northeast. The minimum effective fetch of $26 \mathrm{miles}$ is from the north, the maximum fetch, of 140 miles, is from the west-sontiswest. A study of wind records shows that the maximum relocity recorded for a 4 hour period was a Beaufort force of 10 ( 56 to $65 \mathrm{mph}$ ), and was observed 12 times during the 17 year period of record - twice from the southeast, once from the south, six times from the southwest, twice from the west and once from the northwest. Therefore, during the period of record $50 \%$ of the maximum velocity storms, each such storm occurring on an average of once in about three jears, came from the direction of longest fetch. Neglecting the development of waves occurring prior to such a 4 hour portion of the storm, wind of this velocity and duration acting over the 140 mile fetch would develope a deepwater wave on the order of 16 feet in height. Further inspection of the records indicate that $27 \%$ of the total wind duration and $30 \%$ of the total wind movement is from the southwest. The shallow depth of the lake causes the larger waves to break appreciable distances from shore resuiting in complex wave patterns. However, dead roll or swell sonetimes runs as long as 24 hours after a severe storm of long duration.

Vave refraction studies of the area fail to show apprectable converm gence or divergence in or thogonals prior to the wave breaking point which indicate a more or less constant beach slope. Waves from the northwest appear to have a smaller energy 1088 due to refraction than from other directions.

Wind data show that predominent direction of wind movement is from the southwest. Since the longest fetch is also to the southwest, it then follows that predominent direction of littoral current and drift is from the west to east in this portion of Lake Brie. Conclusions as to the prodominent direction of drift are substantiated by the fact that the larger quantity of accretion occurs to the west of impounding structures. Harbor structures at Conneaut, Ohio prevent any significant amount of material of beach bullding size from passing that point, therefore, the source of beach material arriving at Presque Isle then comes principally from bluff and beach exosion between Conneaut and Presque Isle.

Levels of the Great Lakes fluctrate from year to year and from month to month during each year depending upon the rolume of water in the lakes. There are two fluctuations of this type occurring simaltaneously. One is a long term variation with a period in terms of jears, which follows gener- 
CASE HISTORY OF SHORE PROTECTION AT PRESQUE ISLE PENINSULA, PA.

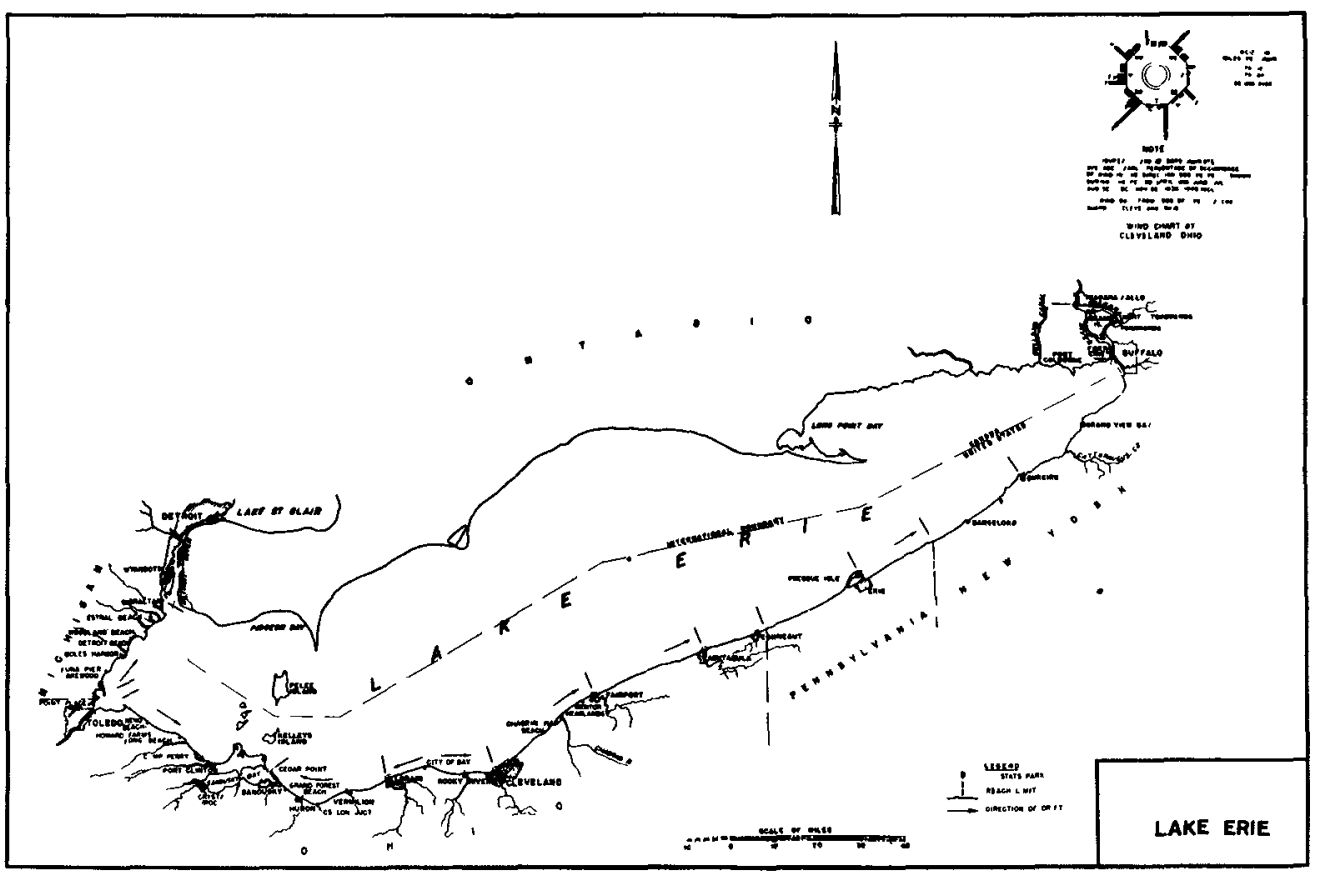

FIg. 1.

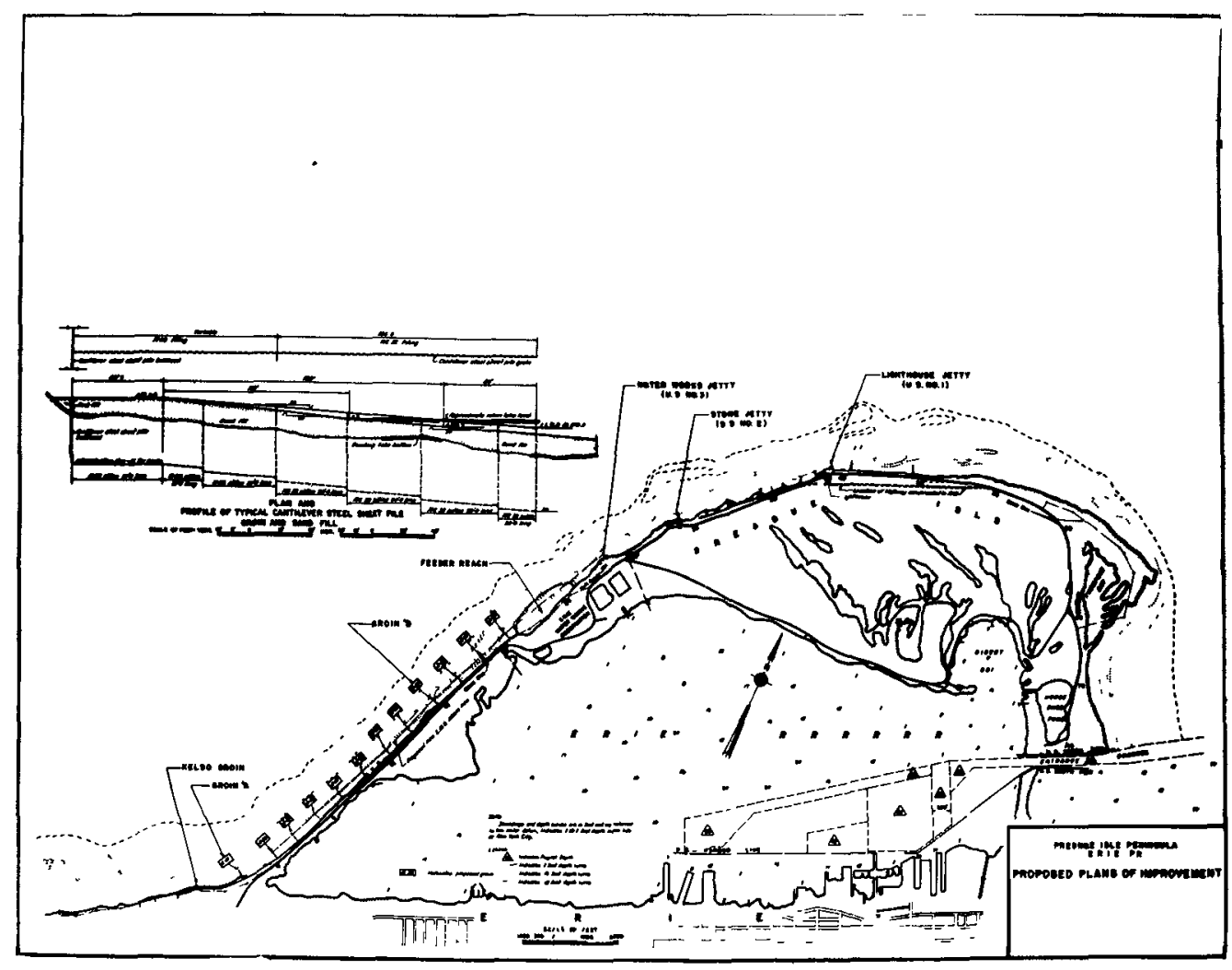

Fig. 2. 


\section{COASTAL ENGINEERING}

ally the trend of precipltation; and the second is a seasonal fluctuation which follows generally the seasonal pattern of precipitation runoff. In addition, the stages at any given locality fluctuate due to unbalance or tilting of the lake surface, caused chlefly by wind and differential bam rometric pressures. These short perlod fluctuations vary in size from a few Inches to many feet, according to location and cause, and are superImposed on the seasonal and long range fluctuations.

The effect of the level of Lake Irie on the degree of erosion has been demonstrated by the breaching of the neck. Hach of the breaches, which occurred in 1828, 1833, 1874 and 1917, was preceded by several years of relatively high lake level. Pertinent data on levels of Lake Inis are shown in Table 1.

TABIE 1

\section{WATIHR IETRI FLUCTUATI ONS}

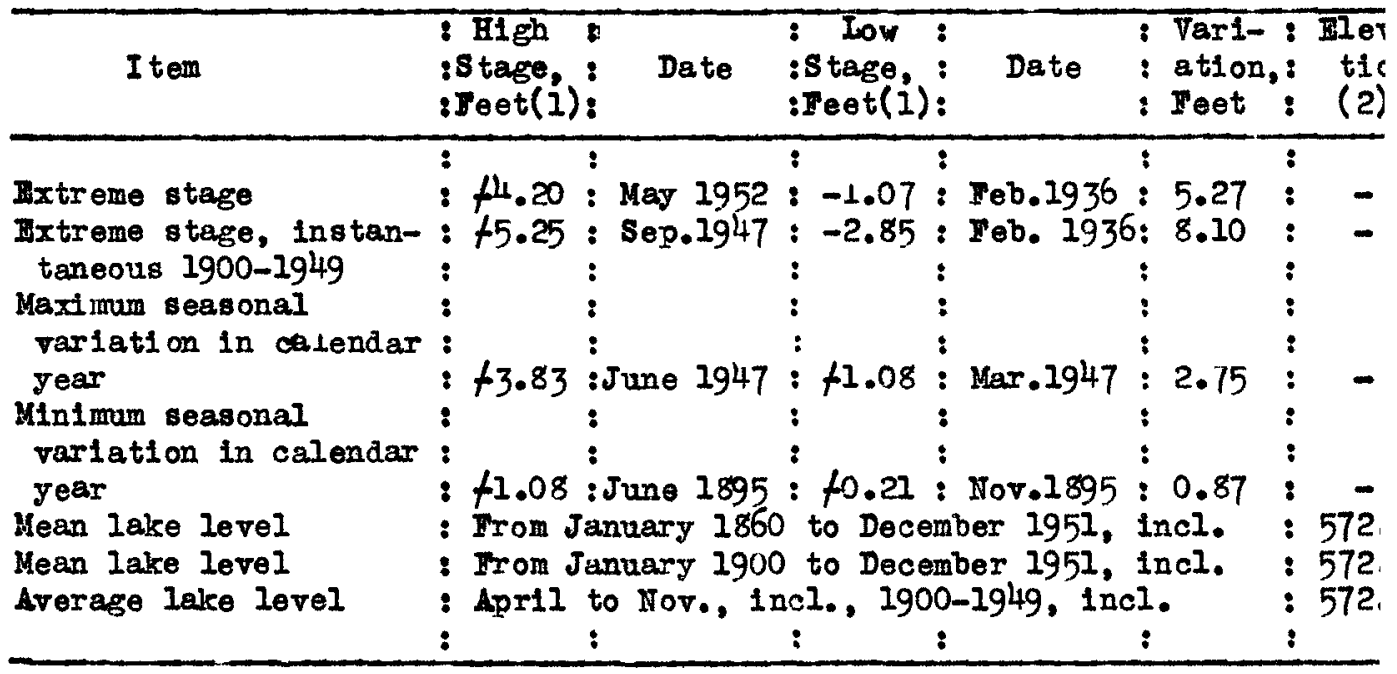

(1) Referred to low water datom, 570.5 feet above mean t1de at New York O1ty. All stages computed from monthly means, except instantaneous high and low.

(2) Referred to mean tide at New York C1ty.

Ice action is another factor to be considered in the design of shore protective measures. Ice forms along the shore of lake inile in years of average winter temperatures, but in more severe winters the entire lake surface freezea over. Generally, the lce begins to form In shallow water along the shore in early December and eventually attains an average thickness of over 12 Inches. Usually by early March the ice becomes honeycombe breaks up and forms into moving fields. 


\section{CASE HISTORY OF SHORE PROTECTION AT PRESQUE ISLE PENINSULA, PA.}

Ice be beneficial or harmful in its effect on the shore or shore structures. The harmful effects are principally from the battering of structures by floating ice, particularly auring heary ice floes following the spring breakup, and from uplift presgures on structures. Beneficial effects generally occur from the following ice conditions which provide protection from wave action.

a. Usually in early winter ice forms on shore and shore structures from spray, at times the ice reaching a height of 12 to 15 feet above lake level.

b. Storms usually break up the ice flelds in early winter and build windrows offshore. These, at times, attain a helght of 10 to 15 feet as far out as one-half mile from shore.

c. In the midale of winter lce forms a solid covering for several miles offshore.

At Presque Isle $1 \mathrm{t}$ is considered that the benefits derived from ice more than balances the adverse effects. These beneficlal effects were 1llustrated by a severe storm on $\mathrm{Karch} 25,1947$ when the east end of Iake Erie, including Presque Isle, was protected by ice and remained undamaged while the Cleveland area and the area further west, where the lake was free of ice, was seriously damaged.

\section{SHORE PROTEO TIVI MHASURES PRIOR TO 1939}

In 1679. Lasalle, the French explorer, built and launched the first vessel to sail on Lake Irle at a point on the Niagara River about six miles above the Falls. As early as 1669 the Hudson Bay Corpany transported 1ts goods and pelts in batteaux on these and western waters. In 1753 during the struggle with the Inglish for possession of the Great Lakes Region, the French built a fort at Presqu'ile, meaning "nearly an island", and garrisoned it with 100 men. Then, as now, the Bay of Presqu'lle furnished one of the best natural harbors on Lake Brie. After the fall of Quebec in 1759 the French lost their grip in the Lakes Region, and Fort Presqu'ile was abandoned In 1760. The harbor at Presque Isle had been considered by both the French and Thglish as an important point of communication and defense, and as a base for supplies between Pittsburgh, Niagara and Detroit.

Following the War of Independence the United States came in to ownership of this portion of the country, and in 1792 Pennsylvania acquired the peninsula by purchase from the U.S. The title to the Peningula was destined to change hands again, however, for in 1871 the Commonwealth of Pennsylvania conreyed the title to the $U$. S. for the purpose of national defense. In November 1922, the U. S. by Act of Congress, reconveyed the title to Pennsylrania for use as a park. The first permanent American settlement on the site of Irie was established in 1795 by the Population Land Corpany who laid out a town facing the harbor, and in conformity with an act of the General Assembly provided for a survey. The name Irle was given to the community (F1g. 2). 


\section{COASTAL ENGINEERING}

The peninsula was breached for the first time of record in the fall of 1828, however, the breach closed naturally in the winter of $1828-29$. In 1833 a breach occurred in the neck of the peninsula immediately southwest of the area now occupied by the Water Works Reservation. After examination and study, it was sugges ted that a second entrance to the harbor from the west be provided through the breach. However, it was recommended that the effect of the breach be studied for a year or two before any plan was decided upon. By 1835 the breach had widened to the extent that where trees were thick in 1824, there was now an opening nearly a mile wide. The opening appeared to be increasing continually and to threaten the whole peninsula. A plan was submitted in 1835 to close the breach by stone fllle cribs, leaving a channel 400 feet wide, thereby making entrances at both ends of the harbor.

In 1836 construction of the cribs began and by 1839 about 4,500 feet were completed. From 1840 to 1844 no appropriations were made by Congress and during this period a portion of the incompleted cribwork was destroyed leaving a breach of about 3,000 feet in with, the nor theast end of the peninsula virtually remaining an is land. By 1852 practically all the cribwork had been destroyed. In 1853 a project of revetting the shore with brush and stone was begun. By 1856 the prospect of restoring the original shore line was in sight. An evident econony move by Congress ensued and for a time no appropriations for the project were made. However, by 1864 the breach was entirely closed by natural shore processes.

In 1870 a Board of Ingineers, Corps of Ingineers convened at Brie to consider the condition of the peninsula. They were of the opinion that the harbor was in no immediate danger from the action of lake waves, but sugges ted that as a precaution against possible damage due to a succession of years of high water accompanied by severe storms that the narrower portions be reinforced. They advised the planting of silver poplar or beec trees where the vegetation was sparse. In 1871 and 1872,350 loads of brus and 187 cords of stone were used in revetting the shore, and 50,000 young trees and slips were planted for protection of the peninsula by vegetal cov

In November 187 't a heavy gale again breached the neck. Repairs began in 1875, the plan being the construction of a bulkhead of timber piles and plank built to a height of about six feet, riprapped on both sides with stone. Following the breach it was recognized that the experiment of relying upon trees alone to protect the low portions of the peninsula had falled. Construction of the bulkhead was completed in 1877 .

The first groins, elght of which were located along the neck and one on the outer section of the peninsula, were constructed in 1881. The groin conslsting of closely spaced timber piles, were spaced 200 feet apart at right angles to the shore and extended to the six-foot depth. In 1883 and 1884 additional timber pile jetties and a timber pile bulkhead were built, but by 1887 they were all in ruins. The early destruction of all timber structures prorpted the District Ingineer to state that any timber structur placed to protect the neck mast be replaced every six or seven years. 


\section{CASE HISTORY OF SHORE PROTECTION AT PRESQUE ISLE PENINSULA, PA.}

In 1885 the Iight House Jetty, the oldest structure now existing on the peninsula, was constructed by the United States near the center of the outer section of Presque Isle. It is a stone filled timber crib groin with a concrete cap on the outer end. In 1936 the inner end was replaced with steel sheet piles. At present the structure is in fair condition and an extensive beach has accreted to the west.

In 1889 a project to construct an offshore breakwater along the neck was begun. The proposed structure was to consist of 6,000 feet of timber pile and wood sheeting constructed alongshore to 3 feet above mean lake level, and 100 feet lakeward of the shore line. In 1890, after 4,500 feet of the breakwater had been completed, approximately 3,200 feet was destroyed during a storm. The contract was then terminated and the project abandoned.

During the periods of 1396-98 and 1916-17 approximately 16,500 wllow, cottonwood, poplar, scotch pine and yellow locust trees; elght bushels of blue grass, shrubs, or chard grass and clover; and 2,725 feet of hedge were planted along the neck. Also during a part of this period, 1896 to 1904 , two timber crib groins about 300 feet long were constructed by the United States. The first, located about 2,000 feet north of the Water Works, was completed in 1900 and the second, fronting the Hater Works was completed in 1903. Hxcept for the addition of concrete caps to each and concrete curtain wall adjacent to the northerly groin to decrease permeability, these groins have required only minor repalrs and are now in fair to good condition. Both now have substantial beaches to the rest.

Abetted by high water, a storm occurring on 0ctober $12-13,1917$ caused a breach in the neck of the peninsula less than 2,000 feet from the mainland. In April 1920, following the storm of December 1917, November 1918 and January 1919, the breach had increased to 1,470 feet. An unsuccesaful attempt was made in 1918 to close the breach with a timber pile balkhead. However, during 1920 - 21 closure was made by the United States with a rubble mound 1,700 feet long placed in a trench excevated to or near bedrock. In 1923 the rubble mound closure structure was extended 2,320 feet northward and about 5,000 linear feet of sand backfill was placed on the harbor side behind the rubble mound. To stabilize the fill rye was sow and poplar and willow trees planted. The wall remeined in fairly good conaition but was too low ( 1 or 2 feet above mean lake level) to provide effective protection during storms at average or high lake levels. The wall was raised and extended as a part of the emergency work performed by the commonvealth during the fall of 1952.

In 1930 following several years of high water an area lmediately south of Mrle Water Works Reservation threatened to breach. To avert the breach the United States constructed 3,320 feet of steel sheet plle bulkhead with rubble mound facing. However, offshore erosi on continued and about 2,600 feet of the southerly section partially failed in 1943 due to settlement of the stone. Realignment and repair of this 2,600 feet was completed in 1944 . In 1947 the nor therly 740 feet of the bulkhead was realigned and repaired. 


\section{COASTAL ENGINEERING}

In 1929 Iake Erie attained the highest monthly average level reached, up to that time, since 1876. This high lake level, with the attending increased erosion, was evidently responstble for the increased constructio: of protective works by the Commonwealth of Pennsylvania between 1927 and 1939. For ease of explanation, this perlod of time is treated as a unit and the construction by the state is covered geographically, from south to north, in the following subparagraphs:

a. In 1927, near the center of the neck, four patented concret sand traps were constructed. These were groin-like structures about 50 feet long with a "T" on the lakeward end. The traps had little effect on the shore line and erosi on continued. In 1930 the United States construct behind the traps, 1,960 foet of steel sheet plle bulkhead wi th stone facin 1400 foot section of this stone facing was repalred by the United States during the summer of 1951 and the bulkhead is now in good condition.

b. In 1931 the state constructed 1,232 feet of steel sneet p11 bulkhead adjoining to the north bulkhead described immediately above and is 1939 extended it an additional 1,385 linear feet northward. A rubble moun facing was added to this latter section of brlkhead by the Un1ted States. This bulkhead is still in good condition. At the junction of these two sections of bulkhead a steel sheet pile groin 220 feet long, wi th the oute: 100 feet curred to the north, was constructed in 1931. The outer 100 feet was destroyed by ware action shortly after construction (about 1939) but the inner 120 feet is in fair condition and maintains a beach from 100 fee to 50 feet wide to the vest.

c. In 1927 - 1932 a precast concrete andtrap, as described in subparagraph $a$, and 9 teel sneet pile groins were constmucted on the 6,001 feet of shore lamediately north and east of the waterworks reservation. The outer ends of several of the sheet pile groins were curved northward. It is of note that none of the curved groins have retained a beach lakewar, of the groin bend. Practically all of the se groins have falled at one tim or another and have required repair. The failures have been attributed to insufficient penetration of the piles, as fallures have generally occurred near the center of the groins where shorter piles vere used. Practically all of these groins constructed normal to the shore line have retained cam pactity beaches. The sand trap 18 still in falr condition and completely filled. However. 1 ts length and height are so small that little change in the shore line results therefrom.

d. Mlong the northeasterly 3,500 feet of the area corered in the preceding subparagraph and just southwest of the Light House Jetty, a steel sheet pile bulkhead ras constructed in 1929 behind the groins. This bulkhead 1s now burled in sand accretion. In 1932 the state constructed 1,500 feet of Imilar bulkhead nor theast of the Light House Jetty. In 193 an 850 foot extensi on was added. Brosion of the offshore and backfill continued and in 1946 the bulkhead falled and a large section of the highw. vas destroyod. In 1947 - 48 the tate repaired and realigned the bulkhead. added a 250 foot extension northward, relocated the highray, and construct, 2 groins in this section of the bulkhead. The following winter the groins 


\section{CASE HISTORY OF SHORE PROTECTION AT PRESQUE ISLE PENINSULA, PA.}

were destroyed. Since that time the bulkhead has falled in numerous places and has been outflanked. The present shore line of the peninsula is landward of the bulkhead.

\section{INTHRIM BRACH HROSTON CONTROL COOPTRATIVE STUDY}

In April 1939 the Commonwealth of Penngylvanta applled to the Corps of Ingineers for a cooperative beach erosion control study, under author1 ty of Section 2 of the River and Harbor Act approved July 3, 1930, for the purpose of developing plans to prevent further erosion and to stabilize the beaches. A physlcal survey of the peningula was made in 1939 and existing data on the area were complled for analysis. However, due to the limited amount of bastc data avallable and to the lack of knowledge regarding the characteristic action of beach building phenomena along the peninsula the Beach Brosi on Board in an interim report dated April 1942 recommended the following action:

a. Mxtension of the bulkhead along the neck of the peninsula;

b. The construction of two experimental rubble mound groins extending lakeward 300 feet from the bulkhead line;

c. That upon the completion of the bulkhead and groins, four semi-annual surveys be made to determine the effectiveness of groins of this design;

d. That a topographic and hydrographic aurvey of the peninsula be made prior to construction to serve as a base for comparison; and

e. That formulation of a complete plan of improvement be deferred until the results of the surveys described above are avallable.

During July and August 1943, the Office of the District Engineer, Buffalo under to ok the following:

a. Beach profiles for the entire peninsula. The profiles extended from the baseline of the 1939 survey to the 18-foot depth contour;

b. Vertical aerfal photographs of the peninsula;

peningula.

c. Ground photographs of conditions along the lake shore of the

Comparison of the 1939 and 1943 profiles indicated that more or less continuous erosion had occurred in the Western section (between the mainland and the Water Works Jetty). The volumetrlc change was a loss of about 202,000 cubic yards, of which about $80 \%$ occurred above the low water datum contour. The eastern section (from Water Works Jetty around the distal end to the Harbor Jetty) comprised a generally prograding zone. The to tal accretion in this area amounted to about $1,050,000$ cubic yards, of which about $90 \%$ occurred off shore. 


\section{COASTAL ENGINEERING}

The above information was compiled by the District Ingineer in an interim report of September 1943. The report also outlined emergency protective works and test structures to be constructed at this time. The works consisted of:

a. A rubble mound wall 2,750 feet long extending nor theasterly from the Xelso groin at the root of the peninsula. Near the center of the wall groin "A" was built perpendicular to the wall and extended 300 feet lakeward.

b. Realignment and repair of the steel sheet pile bulkhead constructed by the state in 1939, addition of rubblemound facing lakeward thereof, placement of sand fill behind the bulkhead, and construction of a groin "B" similar to groin "A" at the downdrift end of the bulkhead.

c. Construction of a rubble mound facing on a stone blanket lakeward of the steel sheet pile bulkhead constructed by the United States in 1930 southward of the water works. Also realignment and repair of 800 feet of the bulkhead and placement of sand fill behind the bulkhead.

The first post-construction survey was made by the Buffalo District Ingineer in April 1944. At the time of this survey the construction of bulkheads was not yet complete al though the groins had been completed the previous fall. The results of the survey indicated accretion ranging from 0.0 at about 1,000 feet southwest of the experimental groins " $\mathbb{A}^{n}$ and "B" to about $a^{\prime} 1$ foot thickness at the groins. The accretion at the groin extended about 500 to 600 feet off shore. There was also evidence of a leveling of off-shore bars and valleys in the area. The remainder of the peninsula continued to erode slightly except at the distal end where accre tion was evident. There was but one major storm between the surveys of 1943 and 1944. This occurred in December 1943 and breached the bulkhead at the nor therly end of the neck. This report recommended that the remair der of the post-construction surveys be made annually, in late summer, rather than semi-annually.

The second annual post-construction survey was made in Augrast-September 1945. Between the first and second surveys the Commonweal th of Pennsylvania constructed two permeable groins near the nor th-easterly end of the peninsula. The location of the state groins were such that Impoundment at the experimental groins were not affected by their presence.

Conditions during the three years prior to this survey were somewhat more severe then typical years as lake levels were high. The high levels allow damaging waves to progress further inland with consequent increased erosion of the shore. The second survey indicated that (see Fig. 2):

a. The permeable groing installed by the state had settled 2.5 to 3.0 feet. Inspection indicated that some accretion occurred with easterly winds but erosion occurred with more frequent westerly winds;

b. General erosion had occurred in the unprotected areas excer at the distal end of the peninsula; 


\section{CASE HISTORY OF SHORE PROTECTION AT PRESQUE ISLE PENINSULA, PA.}

c. No appreciable changes had occurred in the sections where protective works (groins and bulkheads) were constructed, except at groin "B" where a three foot deep accumulation of sand occurred adjacent to the updrift side. It was concluded that groin "A" was providing protection although the amount of onshore accretion was not as large as at groin "B".

The third post-construction survey was made in July - Angust 1946. The report on this survey recommended that the fourth post-construction survey include a topographic and hyorographic survey of the entire peninsula. The third post-construction survey revealed that over the period studied the protective works were at least partially successful. Groin "A" collected a beach to the west although erosion occurred to the oastward for a distance of about 1,000 feet. The gro in was in good condition and the rubble mound bulkhead backing the area snowed no sign of damage or leterioration. Groln "B" also accreted a substantial amount of material since construction, amounting to a layer four to six feet deep immediately west of the groin. Irosion was evident east of the groin. The bulkhead backing this area remained in good condition. Bulkneads in areas not protected by groins for the most part were in need of repair. Unprotected areas had eroded generally and in the area of the waterworks a length of paved highway was destroyed.

\section{COOPHRATIVE COMPRHHIWISIVE BEACH IIROSION CONTROL RHPORI}

1 Cooperative Beach Brosion Control Report was prepared by the United States in cooperation with the Commonwealth of Ponnsylvania, acting through the Department of Forests and Haters and the State Park and Harbor Conmission of Hrie, Pennsylrania. The elements considered in the design analysis and the plan of improvement recommended in the report are discussed in the following paragrapho.

In considering the history briefly covered in this paper, it may be noted that the natural tencency of the peninsula is to migrate eastward. This is shown by the constant erosion along the neck and accretion at the distal end; by the persistent breaching of the neck; and, prior to the installation of structures which altered the natural shore processes, by natural closing of the breaches with littoral arift. The essence of the problem is the stabilization of the peninsula under existing conditions. This may be accomplished by protecting the neck and assuring that a sufficient quantity of littoral drift is available in the accreting areas.

A plan consisting of revetment and bulkhead alone was consldered for protection of the peninsula. However, thi metnod was eliminated in the final selection of plans because of advantages of fered by a spending beach. Spending beaches furnish protection and also provide recreational area, a principal functi on of the peninsula. A comprehensive plan using this method was recommended in the report. After reviewing the recommendations of the District and Dirision Ingineers, the Beach Irosion Board recommended the comprehensive plen described in the following paragraphs (see Fig. 2). 


\section{COASTAL ENGINEERING}

The neck, which consists of the shoreline from the root to the Brie Waterworks Reservation, has been subject to large losses of material during closely spaced series of severe storms such as preceded the 1917 breach, and by single severe storns. Fror this reason the plan for the neck Included groins, artiflcial fill, and a bulkhead as a last line of defense. The Exoins are to be spaced 1,000 to 1,300 feet apart, are 290 to 320 feet long, and will incorporate experimental groins "A" and "B" without chenge, and state groin 8 modified to the recommended design. The height of the inner end of the groins, and consequently the design beach berm, is 8 feet above low water datum, or 6 feet above mean lake level, and the grolns extend lakeward horizontalily for 60 feet then on a I on 20 slope to mean lake level. The complete plan consists of construction of two cellular steel sheet pile groins and 7 cantilever steel sheet pile groins, alteration of one steel sheet pile groin, raising of 1,700 feet of stone seawall, constructlon of 1,120 feet of cantilever steel sheet pile bulkhead, and placement of $1,079,000$ cubic yards of sand.

The plan for the remainder is composed of a stockpile of $1,000,000$ cublc yards of sand at the southerly extreme of the Water Works Reservation, an axtificial beach extending from that point to the about center of the reservation and the removal of the outflanked steel sheet pile bulkhead near the center of the outer section of the peninsula (constructed in 1932). The area north of the Water Works Reservation has been fronted by wide beaches in the past and is as sumed to be a natural accreting zone when abundant littoral drift is available. Therefore, it is as sumed that prom tection will be formed by the natural drift in conjunction with erosion of the stockpile and the updrift beach fill. It is believed that this general plan is the most practicable and least expensive method to provide the protection needed.

The Cooperative Beach Frosion Control Report recommended that a project be adopted by the United States authorizing Federal participation by the contribution of Federal funds in amount of one-third of the construction cost of the comprehensive plan described in tne two preceding paragraphs. This is the maximum Federal participation permitted by the policy established by Public Law 727, 79 th Congress, which permits Federal participation in beach protection projects. The total cost of the proposed plan is $\$ 5,259,000$ of which the United states share would be $\$ 1,753,000$. Maintenance of the project wII be the responsibility of local interests.

During the high water of 1952 the condition of the southernmost 2,000 feet of the neck again became critical and the Commonweelth of Pennsylvanis appropriated approximateity $\$ 600,000$ for emergency work. The Commonwealth desired to construct emergency work that would also become an integral part of the comprehensive plan. During the late summer of 19522,800 feet of rubblemound bulkhead was raised to about 6 feet above average lake level. It is understood that the Commonwealth plans to also construct six groins in thts area during sunmer of 1953. 


\title{
CASE HISTORY OF SHORE PROTECTION AT PRESQUE ISLE PENINSULA, PA.
}

\author{
SUMMART
}

In the 117 years in which protective works have been applied to Presque Isle Peninsula there have been many types of structures and many methods of protection attempted. The large forces involved proved too great for vegetal growth alone to be effective in the porous material which forms the peninsula. Timber structures other than the rock-filled crib groins have had short life. Bulkheads exposed to the direct action of the waves have required frequent and expensive repairs. As demonstrated by the impoundment at the privately omed Kelso groin at the junction of the peninsula and the mainland, and at experimental groins "A" and "B", a spending beach gives best results. The problem is then the method to be used in forming the beach.

Frosion appears greatest at the root of the peninsula, decreasing in extent to about the Water Works Jetty, beyond this point accretion is predominent when sufficient meterial is avallable. Persistent breaching Indicates that the peninsula is subject to rapid losses with high lake levels and severe storms. Based on thls analysis of characteristic action, sand fill alone would not sufflce at the neck and retaining structures are indicated. From the mainland northward along the neck and fronting the Water Works Reservation an artificlal beach with a stockpile at the Water Works Reservation to provide littoral drift and groins to hold the beach along the neck apnears loglcal. The shore easterly of the Water Works appears to be a natural accreting zone, therefore wi th the natural amount of Ifttoral drift restored and the aditional material availabie from the stockpile it is believed that this zone will form the needed protective beach by natural processes. The comprehensive plan should be followed for best results as experience has shown that piecemeal construction has not been effective.

\section{ACRINOHLEDGFAMAN TS}

Appreciation is expressed to Mr. W. I. McDonald, Great Iakes Dirision, Corps of Ingineers, for his constructive criticism and afd in preparing this paper. Appreciation is also expressed to Mr. H. W. Nelson, Great Lakek Division and Mr. G. A. Iynde, Buffalo District, for thelr helpful review and corment. 
